\title{
Drivers and Impacts of China's Economic Engagements in Nigeria: Focus on Infrastructures Investment
}

\author{
OJO, Ademola Eyitope \\ Physical Planning Department, Federal University, Oye Ekiti, Nigeria
}

Tel: 234-803-258-2453 E-mail: ojconnect2@yahoo.com

Received: October 11, 2020 Accepted: November 23, 2020 Published: November 25, 2020

doi:10.5296/ijim.v5i1.17981 URL: https://doi.org/10.5296/ijim.v5i1.17981

\begin{abstract}
China's growing presence across African continent and with reference to Nigeria has variously attracted debates and mixed feeling amongst scholars and policy makers. Severally considered and described initially as ideological and political, cultural and adventurous, etc., but the phenomenal expansion of the engagement and relationship into trade and investment across economic sectors particularly infrastructure development, has many things to desire. While the public debate accentuates the imperativeness of Chinese infrastructure financing schemes and its roles in economic growth and development in Nigeria, yet vital questions on China-Nigeria economic engagement subsist. This study investigated and examined specifically the nature of the driving factors and the impacts of the economic engagement with particular interest in infrastructures investment and development. Using a non-probabilistic and qualitative research design method on secondary data sources, the study discovered that China-Nigeria economic engagement is propelled by economic, institutional, political and perception drivers with divers mixed impacts; and conclusively described the engagement as goodly-bad or sweet but bitter. This study contributes to the asymmetric view of China-Nigeria relationship by positing a balanced position from infrastructure investment perspective. The study therefore recommended that government policy makers ensure that Chinese investments alone in Nigeria's national infrastructures development do not and should not substitute constitutional government responsibilities, that institutional frameworks must encourage momentous indigenous private investment capital inflow into infrastructure sector, going forward, China-Nigeria engagement policies must promote purposeful, environmental, human capital, and people-centered sustainable development goals in Nigeria amongst others.
\end{abstract}

Key words: China, Drivers, Economic, infrastructures, Nigeria 


\section{Introduction}

Recent public discourse about Africa dwells on the desire for provision of infrastructures and recognition of infrastructures' roles in economic growth and development. African Union (AU) in Aspiration 2 of Agenda 2063 affirms, by 2063, the necessary infrastructure will be in place to support Africa's accelerated integration and growth, technological transformation, trade and development... High-speed railway networks, roads, shipping lines, sea and air transport, as well as well-developed ICT and digital economy. Also, the United Nations Sustainable Development Goal 2030 Agenda emphasizes and dedicates specifically goals 6, 7 and 9 to addresses the need for clean water and sanitation, access to affordable, reliable and modern energy services and building resilient infrastructure in order to promote sustainable human progress, industrialization and fostering innovation.

Inching towards these lofty goals is the China's most phenomenal growing presence across the African continent- and perhaps in the larger context of economic globalization. This China-Africa engagement and relationship is historical though, considered primarily ideological and political in nature (Shinn \& Eisenman, 2012), but the phenomenal expansion and new vista of the engagement and relationship now features and encompasses a wide range of economic cooperation, investment and trade in strategic sectors of agriculture, telecommunication technology, mining and construction. Namukale and Williamson (2013) asserted that China-Africa engagement is not rhetorical but strongly premised and facilitated by international institutions like Forum on China-Africa Cooperation (FOCAC) and China-Africa Business Council (CABC) and programme like China-Africa Development Fund (CADF) administered by China Export-Import (EXIM) Bank and China Development Bank (CDB). Indeed, China assumed a major trade partner and infrastructure projects financier's role in Africa with total debt finance (loan) of about \$143billion between 2000-2017, while $70 \%$ of Africa's trade exports to China consisted of crude oil, mineral products estimated to be about \$350Billion as at 2017 (Wenjie \& Nord, 2017).

With relatively 20 years of stable democratic political system, growing population of about 190million people, over \$395Bilion Gross Domestic Product(GDP) economic size (largest African economy, in 2018), over 330,000 square kilometers of arable land and huge natural resources especially in the oil and gas and solid minerals (Adewunmi, 2014; Nigeria Bureau of Statistics (NBS), 2019). Nigeria is politically, economically, demographical and strategically very significant in western Africa sub-region, whole of African continent and in the China-Africa economic engagement. China-Nigeria relationship may be historical, since February 1971, linked due to varied factors but central to it is Nigeria's aspiration towards achieving her development goals and concerns with infrastructures development for industrialization and economic growth being and remains the key policy objectives. With the establishment of Nigerian-Chinese Chamber of Commerce (1994) and Nigeria-China Investment Development and Trade Promotion Centre in Nigeria (2001), (Solomon \& Fidelis, 2018) submitted that Nigerian economic transitions and development plans and programmes trajectory have also been in line with this key policy objectives. China's economic engagement in Nigeria has been evident in trade, agriculture but most importantly, critical Infrastructure investment/construction- power, transportation, and information and 


\section{Ml Macrothink}

telecommunication, in three forms of grants, aids, subsidized interest rates and or low interest "concessional" loans (Foster, 2008). For example, the construction of Omotosho, Geregu and Mambila Power Stations, Airports remodeling, new construction or rehabilitation of all railway system in Nigeria, a good number of several kilometers of road networks, expansion of telecommunication systems etc., in the last 15years, are financed, constructed and or operated by Chinese firms and businesses in Nigeria.

Ideally, the extent of the influence and contribution of China-Nigeria economic engagement had exerted significant impacts on improvement of Nigeria's infrastructures development especially in the power and transportation subsectors, with features of knowledge and skills transfer. Basically public infrastructures investment is to respond to growth demand like the railway system and electric power supply, facilitating movement of people and finished products; efficient production process and reduces transaction costs of inputs factors and hence cost of goods, thereby creates demand in the economy; but this is otherwise in the Nigerian economy. Despite the reported huge investment of \$16Billion (between 2006 to 2010) (Okeke, Izueke, \& Nzekwe, 2014), electric power demand is yet weak and inadequate in supply chain- generation, transmission and distribution (Foster \& Nataliya, 2011), though improved to $178.38 \mathrm{kwh} / \mathrm{cap}$ (power consumption per capita) in 2013 compared to the 74.13 $\mathrm{kwh} / \mathrm{cap}$ recorded in year 2000. Transportation investment with loan investment in \$Billions from China, railways, road, sea and air ports are abysmally performing in Nigeria economy.

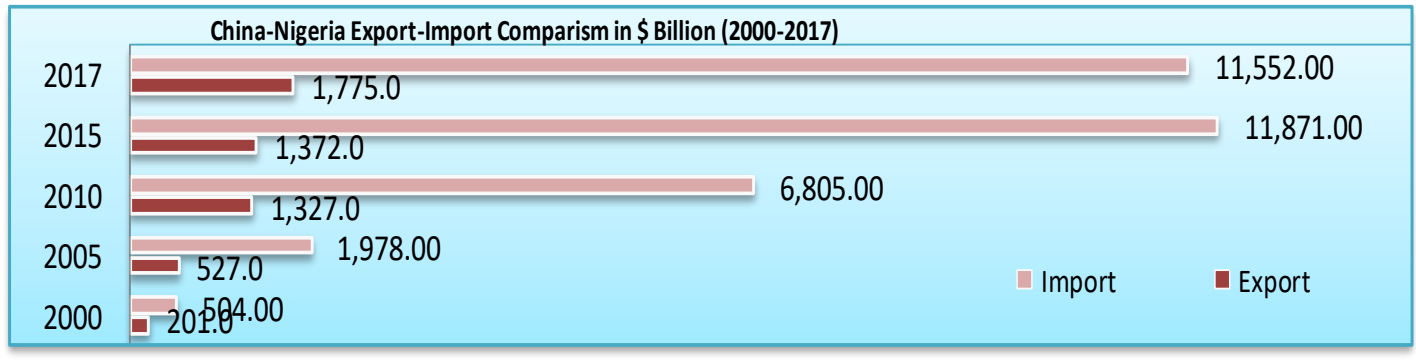

Figure 1. China-Nigeria Export-Import Compare (200-2017)

Source: UNCTAD, 2018 and Author's Computation, 2020.

Figure 1 shows the payment of trade imbalance between China-Nigeria strong to inform enquiries. Nigeria's import continues to rise relative to China's import over the two decades. Therefore, several researchers, observers, current literature and economic discourse have assessed and argued on the nature and implications of the subsisting China's role in Africa and China-Nigeria economic engagement in particular. Perhaps Nigeria's unfortunate over 17million housing deficit, weak technical human capacity, poor road network, failure of the railway system and power supply and or the deficit infrastructure capital spending in the face of increasing population growth(3\% annually) and declining government revenue, poverty rate $(56.38 \%)$, unemployment rate $(15.49 \%)$, inflation rate $(12 \%)$, low fixed capital formation (35\% of GDP), increased cost of industrial production and so on (NBS, 2019) are huge economic attractions to Chinese firms and businesses in Nigeria. In other views, since supply serves to satisfy demand in economic axiom, Nigeria's rich natural resources and 
population's potential market, dwindling China' \$14 trillion GDP, meeting China's huge untapped domestic market due to self-insufficiency in production, strategic economic neo-colonialism of African states etc., are China's economic considerations. The irony of the debate is that China's total export actually exceeded import from Africa and Nigeria and her Foreign Direct Investment (FDI) in Africa only accounts for about 3\% of the stock hence undermining the perception that China is only resources voracious (Wenjie \& Nord, 2018).

Yet, (Raine, 2009, Kelly, 2012; and Chen, 2018) pointed out contentious issues levelled against China's economic engagement concerns in Africa, Nigeria inclusive, with respect to infrastructures development contract thus: avid preference for Chinese labour and materials; poor and fake quality products and services; appetite for host nation's natural resources, project loans tied to Chinese suppliers and contractors and Credit backed natural resources exchange condition like the Angola models. Other areas of concerns are bribery and lack of transparency transaction deals, poor employment practices and human right problems, lack of respect for the environment, trade imbalances etc.

While several studies and economic discourse had assessed China-Africa and or China-Nigeria relationship with respect to trade, security, foreign policy, political alignment, aid and development fund (Parenti, 2009; Ogunkola \& Abiodun, 2010; Okere, 2012; Rindap, 2015; Gimba \& Ibrahim 2018.), very few studies had focused on infrastructures investment and development. These noticed gaps are fundamental and attracted this study especially with respect to providing answers to the questions of; why do Chinese government and businesses invest in infrastructure development in Nigeria? What are the key driving forces behind China-Nigeria engagement in infrastructure investment? What impact has kept the subsistence of the China-Nigeria engagement on infrastructures investment and development?

This study therefore intends to investigate the drivers and impacts of China-Nigeria economic engagement as a general objective but specifically examines the nature and the implications of China-Nigeria economic engagement with particular interest in infrastructures investment and development. This study become crucial considering the excruciating experiences of some African nations like Zambia and Tanzania involve in China's economic engagement on their national infrastructures investment and contributes to the vague and asymmetric views of China-Nigeria relationship by examining it and posting a balanced position from infrastructure investment perspective.

The rest of this paper is organized as follows: the review of related literature, research methodology with the discussion and findings, and the conclusion and policy recommendations.

\section{Review of Relevant Literature}

Different postulations of the classical and modern theories of international trade and complex interdependence theory, underscore the approaches to determinants of international trade and relationship between nation states. The classical theorists (led by Adams, 1776; and David, 1817) advocated the existence and subsistence of absolute and comparative advantages in 
efficiency of labour and costs of production as a result of factor inputs, climate, natural resources, geographical situation differentials to facilitate and specialize in trade of products and by extension, investment in goods and services, where they have absolute and comparative advantages the least (Jhingan, 2010). On their part, modern theorists like (Heckscher-Ohlin \& Paul Samuelson, 1948) propounded that the determinants of international trade is based on commodity price difference, factor endowments and factor prices, and factor price equalization between countries, while Interdependence theorists (Keohane \& Nye, 1977; Richard, 1997), argued that with neo-liberal capitalism, nations fortunes are intricately tied together politically and economically with increasing interdependencies between societies and states regionally and globally.

These postulations may be premised on diversity and uneven distribution in global resourceshuman, natural, financial etc., and advancement in demand dynamics across economies that have necessitated economic integration and cooperation amongst nations. This can be conceptualized further as part of modern economic globalization, which (Rudd, 2007; Sharma, 2013) said speaks to the neoliberal ideology of markets and businesses without barriers, integrated economic activities and nations' interdependence etc., evident in economic policies like trade and price liberalization, labour markets regulations relaxation, inputs and outputs factors global capitalism in production of goods/services and, foreign direct investment (FDI) etc. Arguably, nations endowed with natural resources- human, natural, and so on, suggestively with absolute and cost comparative advantages will ensure her specialization and in furtherance, engages in foreign trade and investment. However, critiques of these theories between, amongst the theorists and other economists are largely based on their outlaid assumptions, approaches and business environment (Fenestra, 2004; Bahar, Ricardo, \& Cesar, 2014; Agbebi \& Virtanen, 2017).

\subsection{China-Nigeria Economic Cooperation}

Nigeria's flirting of economic globalization is evidence in several economic and business treaties entered into e.g. ECOWAS (1975), WTO General Agreement on Trade in Services (1994) African Continental Free Trade Area (2019) and participation in Forum on China-Africa Cooperation (FOCAC) and China-Africa Business Council (CABC). China via (FOCAC, 2012) officially asserted that to "further strengthening friendly cooperation between China and African states under the new circumstances, jointly meeting the challenges of economic globalization and seeking common development' is the principle behind the Forum on China-Africa Cooperation (FOCAC). In any economic cooperation like foreign trade and investment, the objectives, operative principles, programmes and targets are unique. China's economic engagement concerns in Africa, Nigeria inclusive, underscore these rules in economic cooperation with respect to infrastructures development.

However, the debate against economic globalization by way of economic cooperation in its forms has been that it is indeed a necessary evil to the third world countries; neither rejected nor fully applied to its national policy (Sharma, 2013). Some of its anxiety includes; abetting insecurity and arms proliferation, foreign takeovers of key economic sectors (energy, construction, and telecommunication/ICT) and weakens domestic markets, promotes 


\section{$\triangle$ Macrothink}

economic and social inequalities, and negative growth (Umaru, Hamidu, \& Musa, 2013). This supports position that trade liberalization has been severe in many African countries; it's an unimaginable competition between a lion and a dog; unequal yoke and non-mutual cooperation between developed and developing nations markets. Figure 2 compares China's FDI in Nigeria and Nigeria's import from China between 2003-2017. It reveals that China had had modest level of investment in Nigeria from 2003 to 2009, and has being slightly growing but not dramatic.

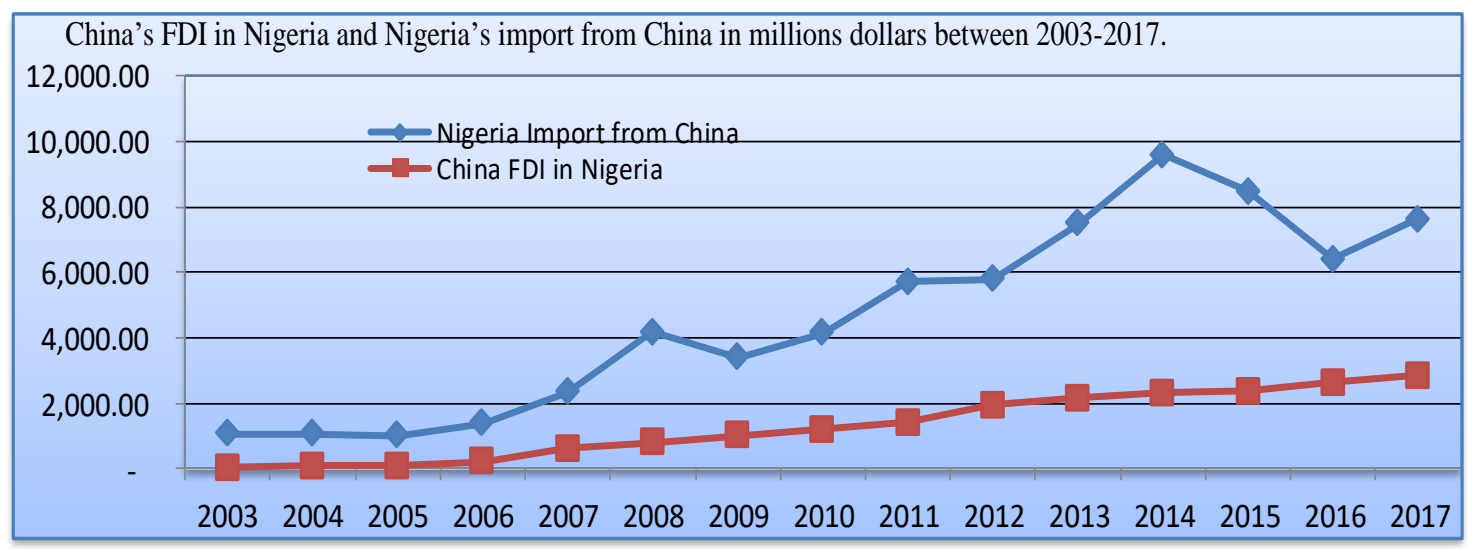

Figure 2. China's FDI in Nigeria and Nigeria's import from China in millions dollars

Sources: Johns Hopkins University School of Advanced International Studies' China-Africa Research Initiative (SAIS-CARI); International Monetary Fund, 2019 and Author's Computation, 2020.

However, Nigeria's export to China, which is majorly crude oil supply, continue to grow from 2003, rose sharply getting to a peak in 2014 but declined during the 2015/2016 global crude crisis. This shows payment of trade imbalance and hence leading to unfavorable Balance of Payment in Nigeria.

\subsection{Infrastructures and China-Nigeria Infrastructures Investments}

In any case, plethora of studies had characterized, disaggregated and generalized the critical roles of infrastructures in economic growth and development, welfare improvement etc., across the Nigerian economy (Edame, 2012; Bello-Schünemann \& Porter, 2017; Babatunde, 2018; Ojo, 2019). This study considers Infrastructures as material, basic and physical economic asset (Buhr, 2009; Foster \& Nataliya, 2011) with distinctive common features (Baldwin \& Dixon 2008, Iyortyer, 2017). Infrastructures are aggregately categorized into Transport (roads and bridges, railways, seaport, Airport), Energy (power generation, transmission and distribution, renewable sources etc.), Water and Sanitation (water supply schemes, sewage systems, irrigation, flood control) and Information and Communication Technology infrastructures. (Program for Infrastructure Development in Africa(PIDA); Infrastructure Concession Regulatory Commission Act (ICRC), 2005; National Infrastructure Master Plan (NIMP), 2013; African Union, 2014).

While Africa's infrastructure requirements are estimated to about $\$ 93$ billion per year (Foster, 
2008), Nigeria's annual infrastructures investment is estimated to be $\$ 30$ billion for a decade. This funding size is not only unavailable but far larger than what public budgetary capital spending can afford hence the desire for alternative capital funding sources in Nigeria. This leads to estimated 208 Chinese registered firms and about 50,000 Chinese (consisting of over 10,000 skilled and construction professionals and tradesmen) in Nigeria, with about 30,000 residing in Lagos(Umejei, 2015). The firms are carrying out various businesses including infrastructure construction, construction material production; mineral exploration etc. Chinese firms are executing more than $\$ 20$ billion worth of railway construction contracts alone across Nigeria amongst other projects in the building and construction economy sector (Akintola, 2016). About $10 \%$ of Nigeria's \$74billion debt is owned to China on infrastructure development (Aljazeera, 2020). Table 1 shows various infrastructures currently being undertaking by Chinese firms in Nigeria.

Table 1. Some recent infrastructures projects undertaking by China in Nigeria

\begin{tabular}{|c|c|c|c|c|c|}
\hline $\begin{array}{c}\text { Class of } \\
\text { Infrastructure }\end{array}$ & Project & Chinese Company & $\begin{array}{c}\text { Project } \\
\text { Cost }\end{array}$ & Nature of Contract & $\begin{array}{l}\text { Project } \\
\text { Owner }\end{array}$ \\
\hline Energy/Power & $\begin{array}{c}\text { 614KM, } \\
\text { Ajaokuta-Kaduna-Kano } \\
\text { gas pipeline. }\end{array}$ & $\begin{array}{c}\text { China Petroleum Pipeline } \\
\text { Bureau and Brentex } \\
\text { Nigerian company, }\end{array}$ & $\begin{array}{c}\$ 2.8 \\
\text { billion }\end{array}$ & contractor-financed & FGN \\
\hline Energy/Power & $\begin{array}{l}\text { 400-megawatt, gas-fired } \\
\text { Sagamu Independent } \\
\text { Power Plant. }\end{array}$ & $\begin{array}{c}\text { China Energy } \\
\text { Engineering Corporation }\end{array}$ & $\begin{array}{l}\$ 550 \\
\text { million }\end{array}$ & contractor-financed & FGN \\
\hline Energy/Power & $\begin{array}{c}\text { Mambilla hydroelectric } \\
\text { Dam }\end{array}$ & $\begin{array}{l}\text { China Civil Engineering } \\
\text { Construction Corporation }\end{array}$ & $\begin{array}{c}\$ 5.8 \\
\text { billion }\end{array}$ & $\begin{array}{l}\text { China Export Import } \\
\text { (Exim) Bank financed }\end{array}$ & FGN \\
\hline Transport & $\begin{array}{c}\text { Remodelling of Nnamdi } \\
\text { Azikiwe International } \\
\text { Airport. }\end{array}$ & $\begin{array}{l}\text { China Civil Engineering } \\
\text { Construction Corporation }\end{array}$ & $\begin{array}{l}\$ 200 \\
\text { million }\end{array}$ & $\begin{array}{l}\text { China Export Import } \\
\text { (Exim) Bank/ Nigerian } \\
\text { Government financed }\end{array}$ & FGN \\
\hline Transport & $\begin{array}{c}\text { Construction of } \\
\text { Deepwater harbor Port } \\
\text { complex, Lekki . }\end{array}$ & $\begin{array}{c}\text { China Harbor Engineering } \\
\text { Company }\end{array}$ & $\begin{array}{c}\$ 1.5 \\
\text { billion }\end{array}$ & $\begin{array}{l}\text { (Exim) Bank/ Nigerian } \\
\text { Government financed }\end{array}$ & FGN \\
\hline Transport & $\begin{array}{l}\text { Construction of Lagos, } \\
\text { Ibadan to Kano railway }\end{array}$ & $\begin{array}{c}\text { China Railway } \\
\text { Construction Corporation, }\end{array}$ & $\begin{array}{c}\$ 7.5 \\
\text { billion }\end{array}$ & $\begin{array}{l}\text { China Export Import } \\
\text { (Exim) Bank financed }\end{array}$ & FGN \\
\hline Solid Mineral & $\begin{array}{c}\text { construction of three new } \\
\text { processing and smelting } \\
\text { factories }\end{array}$ & & $\begin{array}{l}\$ 250 \\
\text { million }\end{array}$ & joint venture & $\begin{array}{l}\text { Zamfara } \\
\text { State }\end{array}$ \\
\hline
\end{tabular}

Source: Author's Computation. 2020 from several sources.

\subsection{Narratives about China-Nigeria Infrastructures Investments}

Many narratives and studies on the China-Africa and or China-Nigeria engagement and relation have been largely polarized but all with mixed results. From the continental perspective, (Han, 2013) major research work on Understanding the Drivers of China's Economic Engagement in Africa, revealed that trade, investment and aid, have been core in 
China's engagement in Africa, given rise to large literary debate. The study's qualitative research approach elaborated on the current debate, the nature and impacts of the relationship and discovered that the driving forces behind the engagement are three aspects of economic, institutional and political with asymmetrical impacts. Han concluded that economic incentives, domestic institutions and political considerations have significantly contributed to China -Africa growing economic relationship and hence recommended both sides to avail measures towards mitigating the negative impacts. Arewa (2016) explored Constructing Africa: Chinese Investment, Infrastructure Deficits, through extensive literature review on the recent trends of China's becoming the dominant trading partner and infrastructures financier in Africa. Revealing that Africa is potentially poised for significant economic growth and future population increases, yet there should be caution paid to processes of Africa's external relationships, and concluded that China's Africa new infrastructure projects are transformative to the wider environment and steps to knowledge transfer of capacity needed for future projects.

Gimba and Ibrahim (2018), examined the relationship that exists between China and Nigeria on economic lines focusing on trade and investment. By means of descriptive qualitative research method, their study revealed that China's leading relation with Nigeria is trade before investment, evident in exchange of Chinese manufactured products for Nigeria's mineral resources, leading to visible trade imbalances in favor of China. They concluded however, that investment can boost trade and vice visa between the two nations resulting in development, and hence recommended more enabling environment by Nigeria authorities for economic relationship to perpetuate. Page, (2018) report dwelt on 'The Intersection of China's Commercial Interests and Nigeria's Conflict Landscape' by examining how Chinese interests intersect in Nigeria's peace and security agenda. The study reveals that Chinese business activities in Nigeria are both pessimistic and nuance oversimplified narratives. Adopting fieldwork and interviews with Nigerian government officials, academics, business leaders and local Chinese companies, Page concluded that Chinese commercial engagement involves trade and tangibly measurable investments yielding positive economic and developmental dividends but not without allegation of institutional integrity questions of bribes, corruption etc., that informs conflict and insecurity. However, it was recommended that Intelligence sharing, working-level communication, risks clouding are future policy decisions for a more secured and stable relationship.

Adunbi and Stein (2019) submitted that there has been a recent significant increase in Chinese businesses operating in Nigeria especially in the post military rule from 1999. Discussing on "The Political Economy of China's Investment in Nigeria: Prometheus or Leviathan?", the study agreed that China's Investment in Nigeria is based on her liberalized economic policy, failure of oil revenue dependency, China's huge mineral demand and related industries and need to increase investment in enterprises that will help generate a growth-oriented diversified China economy. They concluded that the nature and impact of Chinese investments in Nigeria projects the images of both Prometheus and Leviathan.

The noticed gap in the empirical studies reviewed is that many studies had not focused on drivers and influence of infrastructures investment and development, posit a vague and 
asymmetric view of China-Nigeria engagement and do not adopt specific research design/method in analyzing the subject matter. This study intends to fill the gaps by using comparative summative content analysis method in contributing to the China-Nigeria engagement debate.

\section{Methodology}

Due to the nature of this study, the most suitable approach adopted, with slight modification, is the non-probabilistic and qualitative research design using comparative summative content analysis method. It distinctively adopted the research design because of its simplistic nature in analyzing, review and relating study variables. This content analysis method was achieved through detailed elicitation and discussion of sampled secondary data sources-literature; books, published journals, internet materials and reports related to the study variablesDriving Factors and Impacts- with reference to the study location. Tesch (1990) and Bengtsson (2016) had asserted that qualitative content analysis of literary content sources is one of the numerous research methods used to analyze text data, focusing on the de-contextualization, re-contextualization, categorization and compilation of related characteristics of language as communicated with attention to the content or contextual meaning of the text. The work is then presented in a purposively stratified section thus;

\subsection{Economic Incentives Driving Factors and Impacts}

The nexus between China's demand and Africa's supply creates a vacuum to fill. There have been several argument that China-Africa and Nigeria's relationship has experienced unprecedented growth, but largely characterized by China's growing appetite for Africa's natural resources and potential markets (Han 2013; Rindap, 2015). Calder (2009) sternly stated that "China's need for energy and natural resources drives Chinese investment in Africa to a significant degree". Adunbi and Stein (2019) convincingly submitted that Nigeria's over 36billion proven crude oil reserve, over fifty widely distributed and numerous solid minerals, and substantial market and growing consumer population etc., plays a big role in the China-Nigeria economic engagements.

Nathan and Scobell (2012) opined that with the increasing domestic economic and social challenges like huge population and unemployment, slowing average annual growth rate and insecurity that China contend with, a continued ambitions in Africa and Nigeria in focus offers a panacea. China as one of world's leading manufacturer of some materials and equipment, is also facing Asian regional fierce competition, surplus in production capacity and increasingly saturated domestic market, hence Africa and particularly Nigeria with less saturation and low industrial productivity, constitutes a large potential market. Under the "Beijing Consensus", China offers very low and concessional loan facility compared to that of other western development institutions (World Bank, International Monetary Fund (IMF) has been attractive bate for Nigeria government in the face of decline public revenue.

The implications of these has been that Chinese-built and financed infrastructures Africa and Nigeria have helped engaged some Chinese experts and huge non-experts alleged to be part of loan facility conditionality, large consumption of Chinese construction products at the 
expense of local content etc., however, reduce businesses' operating costs, increasing opportunities for profitable ventures, expand the size of domestic production and markets, knowledge and skills transfer etc., essential for Nigeria's economic development.

\subsection{Institutional Policies Driving Factors and Impacts}

Ojo and Balogun (2017) listed, characterized, reviewed and emphasized the need to sustain public policies that enhance Nigeria's building and construction(infrastructures) economic sector. Some of the policies and or laws include: National Electricity Policy that orchestrated the Nigerian power reform by unbundling the old public power authority, liberalized the sector, attracted private investment in the generation and distribution power supply chains etc., and later the Electric Power Sector Reform Act of 2005; National Transport Policies (2003) that also liberalized the sector, attracted private investment, National Housing Policy (2012) that fully attracted private investment in housing development; Nigerian Investment Promotion Commission Act CAP. (2004) provided economic incentives, Free transferability of capital and returns and specifically pursuant to its sections 17 and 18 allows $100 \%$ liberalized ownership of investment by any national in any enterprise except enterprises with activities listed on the 'negative list' which are prohibited for both foreign and Nigerian investors. Nigeria Export Processing Zone Authority Act No. 63 of 1992, re-enacted (2004) applicable across sectors of manufacturing and Oil and Gas, has been extensive explored proviso its sections to establish, regulate, license and monitor EPZ and incentives on tax moratorium and security; Public Procurement Act (2007) allows International Competitive Bidding method in order to encourage global participation in Nigerian market etc.

On continental bases, China's Memorandum of Understanding (MOU) with the African Union to develop transportation infrastructures links in across African states (AU, 2015) and the agreement investments of the South-South Non-Alliance nations Partnership (Booysen, 2007) and other multilateral and bilateral agreement are worthy of consideration. These policies are diversely interconnected and applicable to sectors of the economy and with critical provisions for economic liberalization and others sufficiently attractive economic incentives to Chinese and global investors.

The foregoing created preconditions and incentives for interdependent or even indispensable partnership for trade and investment in China-Nigeria economic relationship. Also, China's economic liberalization policy i.e. "Going Global Strategy" policy on FDI, which largely centers on trade and infrastructure investment, is apt for consideration (Shambaugh, 2013; Hanauer \& Morris, 2014). Besides, the exploitative Western corporations, failure of policy focus on human development more than economic development, aid fund conditionality- UK and USA- to help Africa and Nigeria deliver needed economic infrastructures, created windows for China's infrastructure focused on jobs, training and technology transfer, and full packaged deals in Africa (Foster, Butterfield, Chuan, \& Pushak, 2008; Brautigam, 2009; Kolstad \& Wiig, 2011). China's infrastructure model of investment brings growth objectives,foreign policy with "no strings attached" financial and technical assistance, competitive bidding for resources and construction projects using investment and 
infrastructure loans at near-zero percent interest or allow for repayment in natural resources (Zafar, 2006).

In Nigeria, Chinese FDI is evident in the Export Processing Zones (EPZ) at Onne, Lekki, Calabar and Igbesa, where an estimated 264,000 manpower are engaged in various technical skills trades by Chinese construction and other enterprises (Economist, 2018). This Special Export Free Zone have potentially increased demand linkages and contribute broadly to the structural transformation of industrialization and technology transfer in Nigeria's domestic market.

\subsection{Political Relations Driving Factors and Impacts}

China's attraction to Nigeria's economy is traceable to retinue of the duo's political economy escapades. Notable amongst is the historic diplomatic relationship between China and Nigeria dated back 1971 in Lagos, despite China's questionable support for dissenting and secession by Biafra from Nigeria during the Nigerian civil war (1967-70). Following this, further political ties were established and strengthened with China by Nigeria as part of her "Look East" foreign policy during the West aid cutoff and economic sanctions ridden Abacha military dictatorship years (1993-98) in Nigeria (Ramani, 2016). Also, China's endorsement of Nigeria's quest for permanent membership of the UN Security Council, reciprocating Nigeria's and Africans reinforced position for China's recognition by the UNO in the 1960s and during her 1989 territorial disputes in Taiwan region making China to reevaluated her foreign policy approaches (Taylor, 2006).

China's sustenance of state capitalism, where State institutions act as the major economic players across sectors such as energy, construction etc., has shown a resilient role in promoting own economic modernization process and economic engagement with Africa states like Nigeria (Taylor, 2007). Unlike some other weak African nations, China's foreign policy of "non-interference" in the domestic affairs of her investment host nation has important role and serving her economic interests in Nigeria. This has no doubt helped her pragmatic mercantilist approach and negotiating deals power with successive governments. Though Chinese business activities in Nigeria appears to yield real socioeconomic benefits (Page, 2018), indirectly some also fuel criminality, perpetuate poor governance, and stoke communal tensions that have generated much attention among experts and practitioners.

The impacts have been a mixed; severe in some ways and benefiting in other ways. Wenjie (2015) and (Page, 2018) submitted that China's relationship across African state and Nigeria has led to an inattention to human rights considerations, isolation of rogue governments and support of dictators, and corruptions of repressive regimes and indirectly fueling criminality in Nigeria. However, (Adunbi \& Stein, 2019) conversely asserted that Chinese and Nigerians collaboration has led to new enterprises across states and local governments, improvement in social and economic infrastructure and skill transfer etc., in Nigeria.

\subsection{Perceptions Driving Factors and Impacts}

Public views and opinions expressed by various levels of Nigerians -government officials, businessmen, literate minds etc., have been critical issue of consideration about 
Nigeria-China engagements. Jackson (2019) reported that Nigerians' perception is asymmetrical i.e. positive and negative but largely skewed towards positivity. While the major positive views dwell on Chinese business and infrastructure investments, comparative cost of Chinese products etc., the negative image of China is reflected in the noticed issue of poor quality of products, bad employment practices and disregards for local employees welfare, jobs and business crowding out of the locals etc. (Pew, 2019). Reported allegation of racism by China against Africans due corona virus pandemic and attitudes of Chinese companies in Nigeria accentuated the negativity. These perceptions have been driven by influences of international alarm and mistrust of the West policies against China on Nigerian diverse and vibrant media and few but influential Nigerian public officials and their businessmen cronies believed to have been circumvented from sturdy and corrupt business deals evident in routinely reported bribery cases (Page, 2018).

\section{Conclusion and Policy Recommendations}

An attempt to diversionary contribution to the ongoing debate, this study investigated China-Nigeria economic engagement and specifically examined the nature and the implications of the driving factors and impacts of the engagement with particular interest in infrastructures investment and development.

It emphasizes the diversity and uneven distribution in global resources and interdependency of nation state, which has informed socioeconomic and political integration and cooperation, leading to cultural, trade etc., and other mixed result. In China-Nigeria engagement case, the driving factors are economic, institutional and political in nature while the implications have been mixed; severe in some ways and benefiting in other ways. It can be concluded that China's most phenomenal growing presence in Nigeria is an oxymoron expression of goodly-bad or sweet but bitter.

In view of these findings of the study, it become urgent and necessary policy recommendations to government policy makers to ensure that Chinese investments alone in Nigeria's national infrastructures development do not and should not substitute constitutional government investment responsibilities in the development. Again, institutional frameworks in Nigeria must encourage momentous indigenous private investment capital inflow into infrastructure sector in order to avoid the implications of foreign control of our national assets. China-Nigeria engagement policies must be couched to promote purposeful, environmental, human capital, people-centered and sustainable development goals in Nigeria. Keeping the relationship in close check must involve mechanisms for criticism transparency and integrity of the infrastructure investment funding transactions by strengthening institutional frameworks. Nigeria must quickly development own sustainable strategies to exit the allurement of China's debt financing due to the long term excruciating impact of debt on Nigeria economy.

\section{Acknowledgements}

This study received no funding but exclusively personal efforts and resources of the author; declares no conflict of interest. 


\section{References}

Adebanwi, W. (2011). The Radical Press and Security Agencies in Nigeria: Beyond Hegemonic Polarities. African Studies Review, 54(3), 45-69. https://doi.org/10.1353/arw.2011.0056

Ademuyiwa, I., Onyekwena, C., Taiwo, O., \& Eberechukwu, U. R. (2014). Nigeria and the BRICS:Current and Potential Trade Relations and Their Implications for the Nigerian Economy. Occasional Paper no. 184 (Johannesburg: South African Institute of International Affairs, May).

Adewunmi, D. O. (2014). Introduction to Comparative Economics, a textbook (1st ed., pp. 1-435). Mill World Publication Limited. Lagos.

Adunbi, O., \& Stein, H. (2019). The Political Economy of China's Investment in Nigeria: Prometheus or Leviathan? Prepared for AFEE Panel "The Political Economy of State Capitalism", Paper presented at a workshop in Addis Ababa, August, pp. 1-27. https://doi.org/10.1093/oso/9780198830504.003.0010

African Union. (2015). AU, China Agree Big Infrastructure Deal, NEWS24. Retrieved from http://www.news24.com/Africa/News/African-Union-China-agree-big-infrastructure-deal-

Agbebi, M., \& Virtanen, P. (2017). Dependency Theory - A Conceptual Lens to Understand China's Presence in Africa? Forum for Development Studies, 44(3), 429-451. https://doi.org/10.1080/08039410.2017.1281161

Akintola, L. (2016). Kano's Light Rail Contract: Chinese Firms Are Dominating Nigeria's Rail Sector. Retrieved from http://www.venturesafrica.com/kanos-light-rail-contract-chinese-firms-dominate-nigerias-tran sport-sector

Aljazeera. (2020). China is Africa's Top Creditor, but will it lead debt relief. Retrieved from http://aljazeera.com/amp/ajimpact/china-africa-top-creditor-lead-debt-relief-20041314012962 9.html

Arewa, B. O. (2016). Constructing Africa: Chinese Investment, Infrastructure Deficits, and Development. Cornell International Law Journal, 101(49), 102-139.

Ayodele, T., \& Sotola, O. (2014). China in Africa: An Evaluation of Chinese Investment: Initiative for Public Policy Analysis (pp. 1-33). Working Paper.

Bahar, D., Ricardo, H., \& Cesar, A. H. (2014). Neighbors and the evolution of the comparative advantage of nations: Evidence of international knowledge diffusion? Journal of International Economics, 92(1), 111-123. https://doi.org/10.1016/j.jinteco.2013.11.001

Bengtsson. (2016). How to Plan and Perform Qualitative Research Using Content Analysis. M. Nursing Plus Open 2, 8-14. https://doi.org/10.1016/j.npls.2016.01.001

Booysen, S. (2007). South-South Partnerships: An African Recipe for Growth, Georgia. Journal of International Affairs, 8(35), 35. 
Brautigam, D. (2009). The Dragon's Gift: the Real Story of China in Africa (pp. 1-623). Oxford: Oxford University Press.

Calder, C. (2009). Infrastructure and Growth in Africa (The World Bank, Policy Research 2. Working Paper No. 4914. https://doi.org/10.1596/1813-9450-4914

Chen, Y. (2018). Crossing Rivers, Feeling Stones: The Rise of Chinese Infrastructure Finance in Africa. Bridges Africa, 7(5), 7-10.

Economist. (2018). Chinese Workers and Traders in Africa. The Economist. Retrieved from https://www.economist.com/special-report/2018/05/17/chinese-workers-and-traders-in-africa

Feentra, R. C. (2004). Advanced International Trade Theory and Evidence (pp. 1-345). Princeton, New Jersey, Princeton University Press.

Forum on China-Africa Cooperation (FOCAC). (2012). "Date of Founding" on the FOCAC. Retrieved from http://www.focac.org/eng/ltda/ltjj/t933522.htm

Foster, V. (2008). Building Bridges: China's Growing Role as Infrastructure Financier for Sub-Saharan Africa. Executive Summary, The World Bank. https://doi.org/10.1596/978-0-8213-7554-9

Foster, V., \& Nataliya, P. (2011). Nigeria's Infrastructure: A Continental Perspective. Policy Research Working paper; no. WPS5686. World Bank. https://doi.org/10.1596/1813-9450-5598

Foster, V., Butterfield, W., Chuan, C., \& Pushak, N. (2008). Building bridges: China's Growing Role as Infrastructure Financier for sub-Saharan Africa. Washington, DC: World Bank/PPIAF. https://doi.org/10.1596/978-0-8213-7554-9

Gimba, Z., \& Ibrahim, S. G. (2018). China-Nigeria Economic Relation; The Need for Greater Resource Management for Development. International Journal of Trend in Scientific Research and development, 2(3), 176-188. https://doi.org/10.31142/ijtsrd10812

Han, C. (2013). Understanding the Drivers of China's Economic Engagement in Africa (pp. 1-92). Graduate School of Public and International Affairs, University of Ottawa.

Hanauer, L., \& Morris, L. J. (2014). Chinese Engagement in Africa: Drivers, Reactions and Implications for U.S. Policy. National Security Research Division, RAND National Defense Research Institute, USA. https://doi.org/10.7249/RR521

Infrastructure Concession Regulatory Commission Act (ICRC). (2005). Section 4(2).

Iyortyer, M. (2017). Alternative Infrastructure Financing - Innovative Investment Solutions. Paper delievered at the A Two-Day Specialized Workshop on "Finance and Development of Capital Projects - Emerging Solutions" organized by the Nigeria Institute of Quantity Surveyor, at Westown Hotel, 1 Ayeni 1010 Close, Sheraton Link Road, Opebu, Ikeja, Lagos, Nigeria between Wed 5th - Thurs 6th of July.

Jackson, F. S. (2019). Two Distant Giants China and Nigeria Perceive Each Other. Journal of 
European, Middle Eastern, and African Affairs, Winter, 40-74.

Jhingan, M. L. (2010). International Economics (6th ed., pp. 1-247). Vrinda Publications (P) Ltd. Delhi, India.

Kelly J. (2012). China in Africa: Curing the Resource Curse with Infrastructure and Modernization. Sustainable Development Law and Policy, 12(3), 35-41, 57-60.

Kolstad, I., \& Wiig, A. (2011). Better the Devil You Know? Chinese Foreign Direct Investment in Africa. Journal of African Business, 12(1), 31-50. https://doi.org/10.1080/1536710X.2011.555259

Namukale, C., \& Williamson, P. J. (2013). Chinese State-Owned Enterprises in Africa: Myths and Realities. Global Business. March/April. http://www.iveybusinessjournal.com/topics/global-business/chinese-state-owned-enterprises-i nafrica-myths-and-realities\#.UdsM6o2PVuY

Nathan, A. J., \& Scobell, A. (2012). China's Search for Security (2nd ed., pp. 1-675). New York: Columbia University Press.

Nigerian National Infrastructure Master Plan (NIMP). (2013). Federal Ministry of Economic Planning Policy Paper (pp. 1-147).

Ogunkola, O. E., \& Abiodun, S. (2010). Nigeria-China economic relations. Zenith Economic Quarterly, 5(4), 68-79.

Ojo, A. E., \& Balogun, F. J. (2017). Characterization and Review Of Public Policies Enhancing Nigeria's Construction Sector Sustainability Between 2000-2015. Papers presented at the 3rd Nigerian Institute of Quantity Surveyors Research Conference (3ReCon) held at the Abubakar Tafawa Balewa University, Bauchi, Bauchi State Nigeria.

Okeke, R. C., Izueke E. M., \& Nzekwe, F. I. (2014). Energy Security and Sustainable Development in Nigeria. Arabian Journal of Business and Management Review (OMAN Chapter), 4(3), 63-71. https://doi.org/10.12816/0019052

Okere, R. (2012). Leveraging on Potential of Nigeria's Free Trade Zones for Economic Transformation. The Guardian Newspaper, 35.

Page, T. M. (2018). The Intersection of China's Commercial Interests and Nigeria's Conflict Landscape (United States Institute of Peace, Special Report 428, pp. 1-19).

Parenti, J. (2009). China-Africa Relations in the 21st Century. Joint Forces Quarterly, 52(1), $1-54$.

Pew. (2019). Nigerian public opinion of China. Pew Global Indicators Database. Retrieved from https://www.pewresearch.org/global/database/indicator /1

Ramani, S. (2016). China-Nigeria Relations: A Success Story for Beijing's Soft Power The Diplomat. Retrieved from https:/thediplomat.com/2016/07/china-nigeria-relations-a-success-story-for-beiings-soft-pow 
er/

Rindap, M. R. (2015). An Assessment of Nigeria China Economic Relations from 1999-2014. International Journal of Arts and Humanities, 4(1), 18-30. https://doi.org/10.4314/ijah.v4i1.2

Rudd, R. (2007). Britain and globalisation - past, present and future (pp. 1-68). In Economic Nationalism, The Smith Institute.

Shambaugh, D. (2013). China Goes Global: The Partial Power (pp. 1-347). New York: Oxford University Press.

Sharma, N. K. (2013). Globalization and Its Impact on the Third World Economy. Crossing the Border: International Journal of Interdisciplinary Studies, 1(1), 21-28. https://doi.org/10.3126/ctbijis.v1i1.10465

Shinn, D. H., \& Eisenman, J. (2012). China and Africa: A Century of Engagement (pp. 1-357). Philadelphia: University of Pennsylvania. https://doi.org/10.9783/9780812208009

Taylor, I. (2007). Governance in Africa and Sino-African Relations: Contradictions or Confluence? Politics, 27(3), 139-146. https://doi.org/10.1111/j.1467-9256.2007.00293.x

Tesch, R. (1990). Qualitative research: Analysis types and software tools. Bristol, PA: Falmer.

Umaru, A., Hamidu, A., \& Musa, S. (2013). Globalization and Its Impact on the Performance of the Nigerian Economy. Interdisciplinary Journal of Research in Business, 2(8), 1-16.

Umejei, E. (2015). China's Engagement with Nigeria: Opportunity or Opportunist? African East Asian Affairs: The China Monitor, (3\&4). https://doi.org/10.7552/0-3-4-165

Wenjie, C. (2015). Why Is China Investing In Africa? Evidence at The Firm Level. Retrieved from http://www.brookings.edu/ /media/research/files/ papers/2015/08/ pdf

Wenjie, C., \& Nord, R. (2017). A Rebalancing Act for China and Africa - The Effects of China's Rebalancing on Africa's Trade and Growth. International Monetary Fund, African Departmental Paper Series.

Wenjie, C., \& Nord, R. (2018). China and Africa: Whither the Belt and Road? Bridges Africa, 7(5), 11-13.

Zafar, A. (2006). The growing relationship between China and Sub-Saharan Africa. Retrieved from http://www.chinadaily.com.cn/china/2006/04/30/c ontent-5777-832.htm

\section{Copyright Disclaimer}

Copyright for this article is retained by the author(s), with first publication rights granted to the journal.

This is an open-access article distributed under the terms and conditions of the Creative Commons Attribution license (http://creativecommons.org/licenses/by/3.0/). 